IPPeriodica Polytechnica

47(1), pp. 41-48, 2016

DOI: 10.3311/PPar.9421

Creative Commons Attribution (i)

RESEARCH ARTICLE

\section{Spatial Planning versus Realized Construction in Bratislava: Zonal Planning, a Case Study Dúbravka}

\author{
Peter Horák ${ }^{1 *}$
}

Received 03 May 2016; accepted 19 July 2016

\begin{abstract}
The article deals with the implications of the spatial planning process in Bratislava, the capital of Slovakia. The article highlights the need for the formation of zonal plans as a possible solution to the improvement of a certain territory regarding spatial planning. Bratislava, from the perspective of urban planning and design, is a diverse city representing a model for understanding the formation of the urban structure through various political and economic principles. The dynamics of the city's development after the Second World War was conditioned by new technological and prefabrication constructions, and required new concepts for residential areas that could exceed the geographical barriers; specifically, the Danube River and the Carpathian Mountains, thus enabling further development of the city. In this article, the Carpathian region is presented by a case study of Dúbravka. To understand the developmental process of this area, basic historical, economic, and technical factors are presented. The phases of the realised construction and their comparison with spatial plans show the impacts that affect the functioning of this city part and the city as a whole, to the current day. Positive and negative aspects, potential and new development ideas are described. The existing current spatial plan and the relevant legislation take these aspects into account. The article critically evaluates the current spatial planning methods in the selected area.
\end{abstract}

\section{Keywords}

spatial planning, mass housing, Bratislava, Dúbravka

\footnotetext{
'Department of Urban Design and Spatial Planning, Faculty of Architecture,

Slovak University of Technology in Bratislava

Námestie SLobody 19, 812 45, Bratislava

"Corresponding author, e-mail: arch.peter.horak@gmail.com
}

\section{Broader context of the Bratislava development}

For a better understanding and subsequent solution for the current urban problems, it is helpful to add some background to the development, factors and elements that formed the city. Such formation is better understood through case studies. In this way, different situations can be modelled using historical cross-sections, analysing the problems and factors affecting them. The city of Bratislava is a good example for analysing the process of urban formation concerning both positive and negative aspects. From the perspective of urban planning and design, it is a diverse city, providing a varied urban structure resulting from the implementation of different political and economic principles. Its area, population, structure, and impact of the construction of housing estates, make Bratislava an ideal example to illustrate the broader problems resulting from construction of residential areas after the war.

The city is located on the western border of Slovakia. The first elementary settlements were located here because of the ford across the Danube River (Š́́šky, 1992). Trade routes later used this ford and stimulated the development of the city. Another natural factor that formed city was the Carpathians, which by their terrain protected the settlement, but also restricted the development of urban structures in the later periods (Hruška, 1961).

After the scientific and technological revolution, the city underwent continuous industrialization, prompting the further development of the city. Due to this industrialisation, Bratislava became one of the most important cities during AustriaHungarian Empire (Š́šky, 1992). In the second half of the 19th century, the city's architecture was mainly influenced by Hungarian, Austrian, Czech and partly German architects (Kusý, 1995). In the early 20th century, the most significant collaboration in the city's development was linked with world quality Czech architects (Kusý, 1971). According to Šášky (1992), the First World War period did not influence the development of the city; however, the Second World War ended the natural architectural development of the city, which subsequently broke up in the post-war era of the new regime, in architecture known as socialist realism (Kusý 1975). Šášky (1992) claims 
that Bratislava was the city of many nations. During the Second World War, the city was occupied by Hungarians, who were violently moved away by the Czechoslovakian army. After this act, the city population remained mostly Slovak and Czech.

According to Kusý (1971), urban planning as a new scientific discipline in Slovakia started to be applied in the early 20th century. However, the first urban visions of Bratislava, when facing the existing situation, showed themselves to be unfeasible. This was due to several factors from two directions. From the perspective of the municipality and investors, the main focus was on economic principles. Urban plans have thus become unsuitable documents affecting previously unregulated and freely designed construction. From the perspective of planners, at that time engineers having mostly a geodetic education, city planning was a vision beyond feasibility. In the pre-war and the interwar period, the city was actively initiating the creation of urban and regulation plans, and urban studies. However, they remained largely at a theoretical level for the reasons mentioned previously. The largest urban realizations were just architectural studies about the size of an urban block or several blocks. While architects were aware of the importance of the city planning, the system approach did not allow them to solve problems on a city scale (Kusý, 1971).

According to Moravčíková et al. (2015), planning before the First World War contained specific requirements from investors regarding parcelling of lots and the public interest. After the establishment of socialism following the Second World War, a basis for the realization of huge urban complexes was created. The enhanced power of the state allowed for the vision of urban development on a previously impossible scale. Spatial planning, at that time the "smerný plán" (directional plan), had a sovereign status, which enabled the realization of huge urban concepts. However, the preparation of such a plan was long and could not quickly and sensitively respond to changes in the development of the city. Also, due to the economic situation and the pressure from the state, the visions within the plans could not be realized in all their extent. The development was therefore either mono-functional or specific.

The change came after 1989. Following this, complex Socialist urban plans had become unfeasible. New ownership relations arose, and much state land was privatised. This provided a fresh insight into spatial planning. New individual investors and an active community entered the process of building and development. (Moravčíková et al., 2015)

\section{Mass housing in Slovakia and Bratislava}

Several factors influenced the construction of residential structures in Slovakia and Bratislava. Constantly increasing demands to solve housing issues, along with the development of industrial areas and the need to create the working proletariat, put pressure on mass housing construction (Moravčíková et al., 2011). This was realized in the form of five-year economic plans illustrated by the construction of housing estates (Kusý, 1975). The realization of progressively larger concepts, the lack of a theoretical basis, elementary and rapid realization of construction, failure to address the problems encountered, and the increasing economic pressure in the construction of civil facilities and services, caused increasingly intolerable conditions for life in the mass housing areas (Moravčíková et al., 2011).

Construction of social housing took place in Bratislava in the late $19^{\text {th }}$ century. Since then, several smaller build urban residential units have been constructed. Following the establishment of the socialist regime, residential areas were started on a previously unknown scale. This brought new problems. Increasing pressure to satisfy the needs of housing forced the architects to rapid implementation, without the option to adequately respond to both the architectural and urban situation (Moravčíková et al., 2011). Consequently, the problems of residential structures deepened from the establishment of the first large residential complexes in the 1950s to the termination of their construction in the mid-90s. Even then, providing adequate conditions for dealing with the situation that occurred were not provided. The repetition and emergence of new problems were on-going.

The first post-war plans reflected the eastern urban development of Bratislava. New dynamics and the construction technologies, like prefabrication, required finding new residential areas on the other side of the River Danube and the Carpathians. Examples of this development were laid in the master plan of the city from the 1960s, which founded the current approach of mass housing areas, functional zoning and transportation. Based on this plan, the international competition for Petržalka (one of the largest communist housing estates) was announced.

The first comprehensive urban residential complex built after the Second World War was the Krasňany.residential complex. The principles of the satellite belt town were applied to this complex and other residential units (Jankovich, 1988). Amenities around the perimeter complement the characteristic thin line built-up area. This housing estate was built as the first within the north-east urban development between 1955-1962 (Moravčíková et al., 2011).

Next, mass housing areas appeared in both larger and smaller forms, among which were widespread complexes such as Ružinov, Karlova Ves, Dúbravka and Petržalka (Fig. 1). Petržalka was built after the international competition. The construction of housing estates was completed by the residential area Dlhé Diely, which was built between 1979 - 1995 (Moravčíková et al., 2011).

A specific planning aspect of these mass housing areas was the completion of the project for building permit with a clearly defined developed area. The speed of construction brought a series of outstanding issues.

The urban concept of residential structures based on functional segregation as defined by the Athens Charter also had 


\begin{tabular}{|c|c|c|c|c|c|}
\hline Name of area & Year of project and realisation & Number of residents & Total area & Built-up area & Population density / ha \\
\hline Ružinov & $1960-1968$ & 56214 & 348.35 ha & 43.40 ha & 161 \\
\hline Karlova Ves & $1967-1976$ & 21200 & 90.48 ha & 13.56 ha & 234 \\
\hline Dúbravka & $1965-1985$ & 40000 & 179.31 ha & 29.93 ha & 233 \\
\hline Petržalka & $1973-1980$ & 158000 & 911.05 ha & 73.77 ha & 173 \\
\hline Dlhé Diely & $1979-1995$ & 17000 & 61.62 ha & 10.79 ha & 275 \\
\hline
\end{tabular}

\begin{tabular}{|c|c|}
\hline Name & Authors of architectural projects \\
\hline Ružinov & $\begin{array}{c}\text { Dušan Kedro, Tibor Gebauer, Štefan Ďurkovič, Ladislav Pinkalský, Ilja Skoček, Ferdinand Konček, Ferdinand Milučký. Karol } \\
\text { Ružek, Ĺubomír Titl }\end{array}$ \\
\hline Karlova Ves & Stanislav Talaš, Jozef Fabiánek, Karol Ružek \\
\hline Dúbravka & Imrich Ehrenberger, llja Skoček, Ferdinand Konček, Ĺubomír Titl \\
\hline Petržalka & Stanislav Talaš, Jozef Chovanec \\
\hline Dlhé Diely & Jozef Sliž, Eva Grébertová, Vladimír Ščepán, Vladimír Zigo, Ján Mišík, Daniela Baxová \\
\hline
\end{tabular}

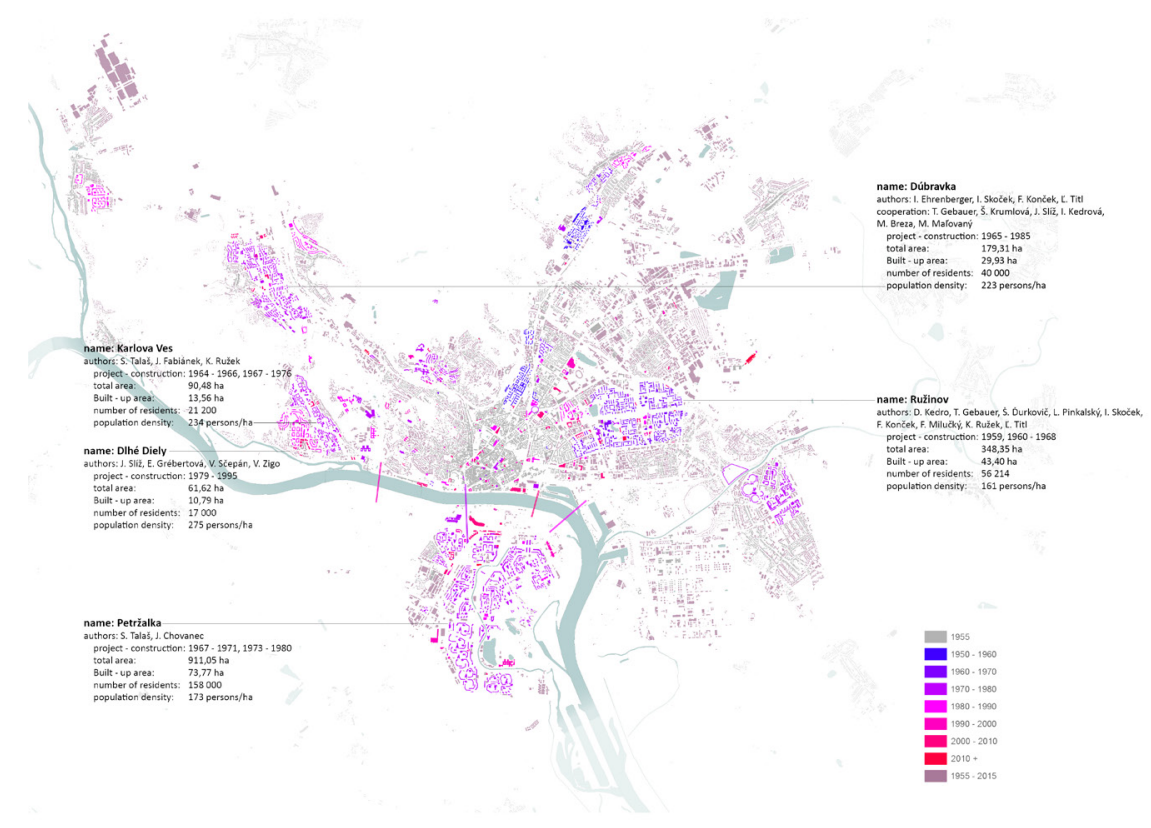

Fig. 1 Map with statistics of housing estate areas built after World War II in Bratislava

adverse impacts. One was the concept of satellite housing estates, which significantly encouraged intercity personal transport by car. This stimulated urban development dependent on the car, while walking connections were perceived as secondary. Thus, large areas emerged for both static and dynamic vehicle traffic. The accompanying phenomenon of motorization resulted in noise and pollutants in the environment, which remain unresolved.

To better understand the problems of Bratislava residential structures, a case study of Dúbravka has been selected to illustrate the issues. Dúbravka is by population the third biggest housing estate in Bratislava. Its satellite location, with several types of residential panel houses, has both advantages and disadvantages. Additionally, its urban analysis can be applied to other similar estates in Bratislava.

\section{Dúbravka}

Dúbravka, originally an agricultural village with a baroque church and a population of up to 1500 , did not alter in structure even when it was connected to the city area of Bratislava in 1945 (Horváth, 1990). The original urban arrangement has remained preserved with the original village still in existence. The masterplan of the Dúbravka housing estate was created in 1966 by Il'ja Skoček. Dúbravka, as a residential area, was planned to be a continuation of the north-east city development and was built close to the Karlova Ves part of the city.

The concept of the new housing development arose independently as an addition to the urban structure of Dúbravka village, which was planned to be preserved in its original state. In Figure 2, the rural character of the villages and their surroundings in 1955 can be seen. In the years 1950 - 1970, even more houses were built in the original village style. After this, the Dúbravka master plan was drawn proposing a large built up area to the right of the original settlement. The new urban structure respected the original communications and connections to the existing village. On the very right, another city part, Lamač, can be seen; at that time it was also a village of rural character (Fig. 2).

The Dúbravka settlement was based on mono-functional subdivision. The main axis of the Dúbravka settlement ran through its centre and carried the main public and personal car 


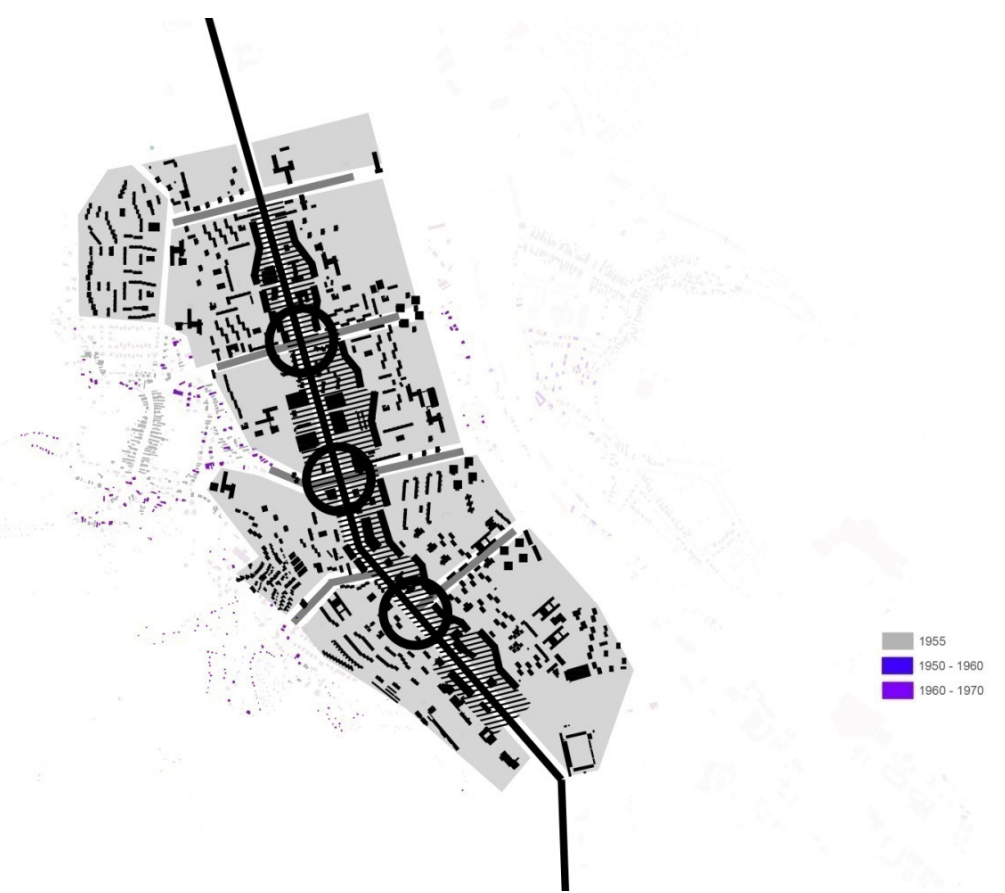

Fig. 2 Reconstruction of original plan of the Dúbravka Housing area and its principles, situated in between villages Lamač and Dúbravka, during years 1950 - 1970

transportation system. Alongside the axis, amenities and public services were planned. The so-called ladder transport system made the residential area and its schools accessible. Despite the complexity of the new plan, only apartment buildings with very basic amenities were built. Constant pressure on housing construction due to population growth and economic insufficiency resulted in a primarily mono-functional character to the area.

In the original projects, mass housing areas included buildings providing work opportunities. There were planned administration facilities, public facilities, light industry, and other facilities, providing work opportunities for local inhabitants.

\subsection{Positive aspects of the settlement}

Despite the fact that specific panel systems and prefabricated building structures were used, variable panel building structures were built (Fig. 3).

Buildings with different plans and heights (like the spot buildings, the plate buildings) together with different configurations were created. Works of art were added to these mass housing areas, especially in the $80 \mathrm{~s}$. The following types of residential buildings were used: T06B, T08B, ZT, ZTB, experimental BA-NKS 11, untypical residential buildings such as a block of flats on Sekurisová 14, individual residential development in Záluchy II, terraced houses on Drobného - Bezeková, mezzanine balcony houses, and residential tower buildings (Moravčíková et al., 2011). These constructions are a nice example of living in the urbanized area. Lots of greenery, grown after the construction of the settlement, improve the environment and add to its value, creating possibilities for healthy living. In combination with low housing prices, the prefabricated houses are still very popular (Melcerová, 2013). This is supported by the original concept of urban schools, which are situated inside the residential area and allow the safe passage of children. Added amenities were a positive step to retain the population in the area, although gradually and taking several decades.

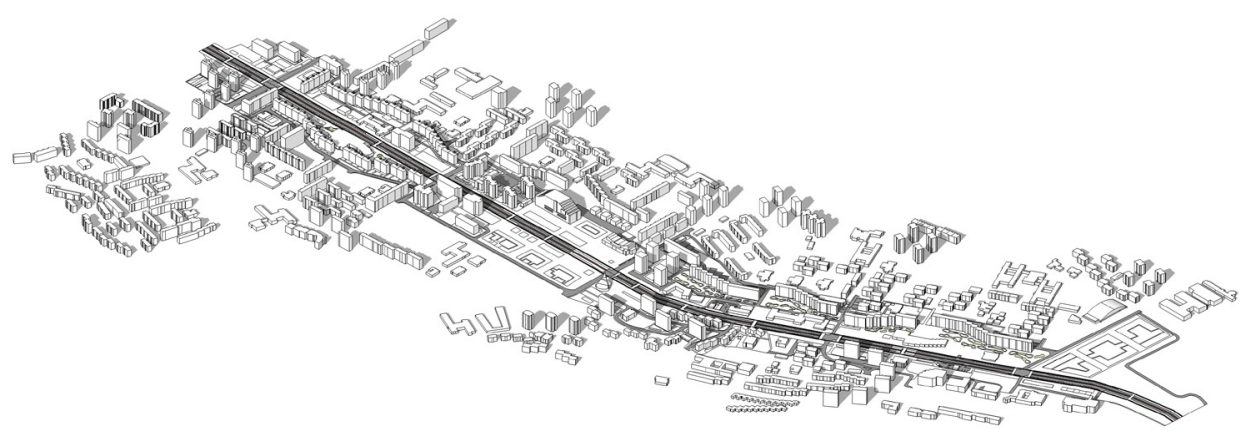

Fig. 3 3D view of the Dúbravka housing area, 2014 


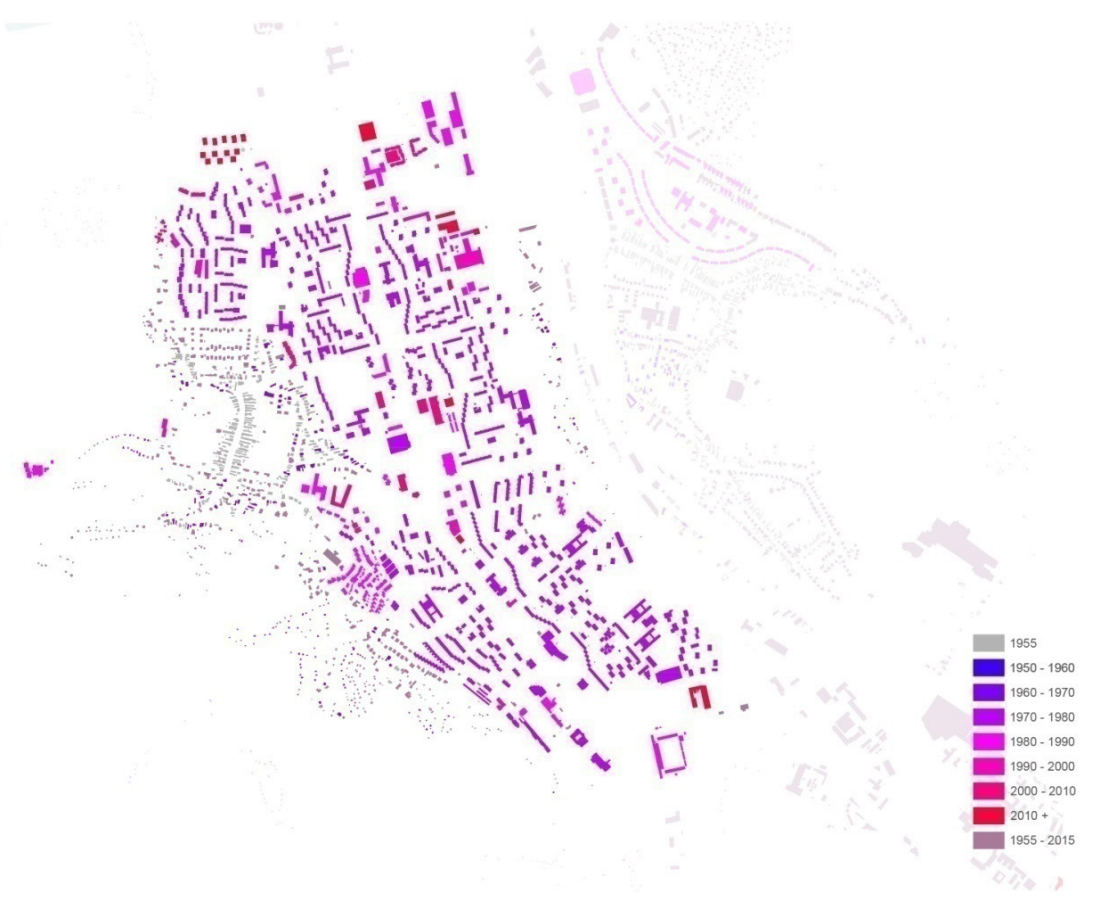

Fig. 4 Historical analysis of the Dúbravka settlement (Lamač on the right)

Apart from the fact that there were shops and services planned in the project, a positive step was that the later integration of public amenities on the ground floors of the buildings was realised. Although this change started to take place later, after the construction of housing units, it was manifested as an appropriate solution enabling access to services for people living nearby. The progress of construction can be seen in Fig. 4.

The establishment of the system of urban public transportation, especially with tram accessibility in the central axis, allowed the transportation of large numbers of people relatively quickly into the city centre or other parts of the city. Considering the current environmental burden, the tramway is still a timeless solution, enabling not only economically feasible but also environmentally friendly transportation.

Apartments that were once state property have become the property of private owners (Melcerová, 2013). This has a twosided effect. On one side, it limits the possibility of intervention by the state. On the other, it has a positive effect on the residents' identification and their positive approach to the environment.

\subsection{Negative aspects of the settlement}

In the new economic situation, after 1989, some institutions, providing working opportunities, ceased to exist. This forced people to find work outside their living area, and as a result caused an increase in car traffic and the load on public transportation.

An inflexible response to the need for new urban structures, from the perspective of spatial planning in the $90 \mathrm{~s}$, led to the construction of more residential houses, even after the completion of the panel housing. (Melcerová, 2013). This increase in population density resulted in more commuting by the inhabitants.
The later construction of hypermarkets has complemented the urban fabric of the housing area. Although this helped to mix the functions in the territory, the concept of new shops and markets was based on personal car transportation (Melcerová 2013). Pedestrian links were cancelled. This concept was hardly acceptable for older citizens.

The urban district concept of schools in the middle of residential areas proved to be a very positive solution regarding security and availability. According to the original urban concept, the domicile of a child is incumbent to the school in the area. This system has changed, and now it is possible to choose which school the child can attend. Some schools have changed from state to private ownership. This change also disrupts the former natural walking distances to schools, although, it allows better selection in the child's education.

Public spaces and pedestrian connections were added during the subsequent decades, however, due to the lack of knowledge, the composition was haphazard, and the functional aspects of the city were applied without a clear concept.

Although the perception of housing estates from the 50s was based on well-lit areas with plenty of greenery, and a low-density the urban fabric, later, this came to be viewed as a negative trait. For effective functioning of a city, it is important to make the best use of space with a sufficiently high population density to maintain sustainable development.

The technical design of buildings, after a few decades, began to prove inadequate. Therefore, new façade insulations started to be applied. They had a twofold effect. First, the new façade protected the panels and the structural iron connections from weathering and external influences. Second, the thermal insulation markedly improved the thermal performance of the 
interior spaces. The colour scheme of façades after reconstruction became a matter of individual expression as well as the need to stand out among the masses of the same objects. However, its arbitrary approach with a multiplicity of colours and geometric compositions clash inappropriately with the environmental complexities. The monotonous panel structure with its incidental composition of colours and shapes create a disharmony within the estate.

\section{Outline solutions}

The urban problems in Bratislava, the capital of Slovakia, are comparable to the problems worldwide in such cities. There are positive international examples that provide successful solutions for these problems. The further stated examples from home and abroad present different constructive solutions. The options are related to small and medium urban problems.

Firstly, the primary problem is that of motorization. While other cities continually and actively approach this problem, in Bratislava, this issue remains unresolved giving reason to increasing car transportation. In the past, this trend was evoked by modernist principles that unfortunately remain today. This form of transportation requires a huge amount of paved asphalt surfaces, spatial and economic demands; it also causes noise, increases pollution and has other negative impacts on the environment.

In the context of the Dúbravka settlement, the problem of motorization, following professional urban recommendations, could be eliminated by shortening the arrival distances. This can be achieved by creating spatially flexible types of services, evenly distributed around the settlement. The service spaces should be adaptable, ready to transform according to real life requirements. This could also lead to the rise of a diverse multifunctional urban fabric. These services could uniformly cover the demands of the local inhabitants and provide labour within the scope of the housing area. Thus, accessible walking and cycling distances could be achieved. This would enable the citizens to forgo expensive car transportation, with the resultant environmental benefits, and improvements to safety and quality of life.

In the areas where car traffic reduction is taking place, special attention to walking, cycling, and public transportation has to be paid. Private investment should be included to generate sufficient resources for creating high quality and alternative modes of transport. Cycle routes should be designed in close connection with public transportation stops. Hierarchically, pedestrian, cycling and public transport should get higher priority over car traffic. In this way, some urban specialists hope to exclude cars from the environment and people's awareness.

Another element that would help to reduce car usage for Dúbravka is connecting the railway station Lamač with Dúbravka by a bus line or cycle route as the current public transport link is insufficient. Such a link would make travelling from the surrounding villages possible and create cheap, efficient and environmentally friendly conditions.
In the $90 \mathrm{~s}$, there were already intentions by architects and urban planners to address the mono-functional character of the area after the process of construction had been completed. However, the complexity of the problem and inflexibility of the authorities resulted in delays. New proposals were incorporated into the master plan after the construction boom in the 90s. However, construction was carried out for several years under the rules of the old master plan (Melcerová, 2013). The continued construction brought further housing units despite that there were already many of them.

The density of housing development should comply with the requirements of intensification. Unregulated construction may form an inharmonious urban structure, not respecting the original buildings and their quality. Consequently, it is necessary to define the places where new construction areas may appear; similarly, in what manner and to what extent they should intensify the environment. According to Štefancová and Gorner (2015), a significant aspect of intensification in the existing residential areas is increasing $\mathrm{UC}, \mathrm{SC}$, and FAR urban parameters (UC - urban character, SC - site coverage, FAR - floor area ratio). Their method was applied in the research of the northeastern axis development of Bratislava. The authors affirmed that methods of intensification could help to solve the problems of the housing area.

Other environmental and economic principles, such as those used in the UK, could stimulate urban areas and self-sufficient urban-architectural conceptual models. These principles include rainwater harvesting for commercial purposes such as flushing and watering (Barton et al., 2010). Other principles include the use of passive solar gains, the use of building materials from close to the construction site, electric cars and the use of car-share combined with cycling, and pedestrian movement designs. Some realized examples provide evidence that these practices make healthy and environment-friendly living available. Applying these principles in an already realized housing area requires a specific approach.

According to Hnilička (2012), the human need to be related to nature results in the tendency to live outside of dense urban structures, the so-called suburbanisation process. Therefore, expanding local services using local natural resources could contribute to mixing people and nature in the city. According to Smit (1992), one approach distributes organic food directly to their consumers thereby strengthening local consumption and the local economy. It also reduces transport distances and thus reduces environmental burdens. This aspect requires the care of nearby green spaces by local inhabitants. For the city, this is a positive factor as it reduces the economic demands and the need for public maintenance of planted areas. Linking rural aspects to the city can stimulate local economic development and partly limit the rise of suburbs around the city. Such an approach is not just theoretical, and its application is increasing. An example is the Determode settlement, where 
people rent public spaces, which are transformed into personal gardens (Gorner, 2014). In Bratislava, there is an example of community gardens in an area of unused land or public space. Spaces below the Slovak Radio station are another example. In London, there is also an interesting concept called BedZED Pavilion, where amongst many environmental initiatives, the supplies for the residential area are distributed from local farms by solar-charged cars (Ritchie and Thomas, 2009).

Other approaches focus on the aestheticisation of mass housing areas, largely by colouring insulated panel homes. By creating characteristic colour marks for each urban complex, the characteristic elements such as tiles and urban furniture can simplify and enhance the identification and interrelatedness of the area.

\section{Conclusion}

Currently, the Bratislava master plan reacts to the regulation of construction. This plan is not specific and detailed; it remains at the level of the city. Such a master plan cannot respond to the degree of detail and accuracy of urban structures in comparison to zonal plans. Aspects and solutions described in this article require a deeper scale than the current city plan. This encourages the debate on changing the concept of spatial planning in Bratislava regarding creating more detailed plans at zonal level. The individual city parts could be captured in zonal plans with the issues and problems of the current urban planning in Bratislava better addressed on a more relevant scale.

A zonal plan would complement the planning regulations of the city and extend the construction legislation. Within Bratislava, the areas can be divided into different zone types. They could be classified as the historic centre zone, stable areas, development zones, structured residential areas, individual residential development, stabilized industrial sites and transforming industrial sites. These zones represent different typological examples. Each of these areas requires a specific approach. The example of Dúbravka represents the category of mainly residential structures with mostly post-war housing.

Zonal plans in an urban structure like Dúbravka should be sensitive to issues of historical identity to prevent ill-conceived disturbing elements. The issue of transportation should be addressed as the fundamental issue: such aspects as reducing car traffic, creating cycle paths and pedestrian connections are of prime concern. Regarding building density and multi-functionality of the area, a zonal plan should identify the areas for different functions: single or mixed, integrated into building parterres or free standing, ensuring walking distances appropriate to the density of the area. In terms of public spaces, it is also a requisite to maintain areas for public use and determine their quality. As part of economic development, the zonal plan should include financing arrangements and incorporate the requirements of investors, as is the case in Vienna, for example. In accordance with European Union standards, the concept of green and environmental aspects should be included. Solar concepts, passive energy gains and recycling processes not only lead to long-term and healthy living but allow the local economy to develop and attract new people and investments into the area. To ensure identification in cities, the zonal plan should also include aesthetic parameters determining the orientation of the area. This can be achieved not only by the colourfulness of façades but also by urban furniture and paving design.
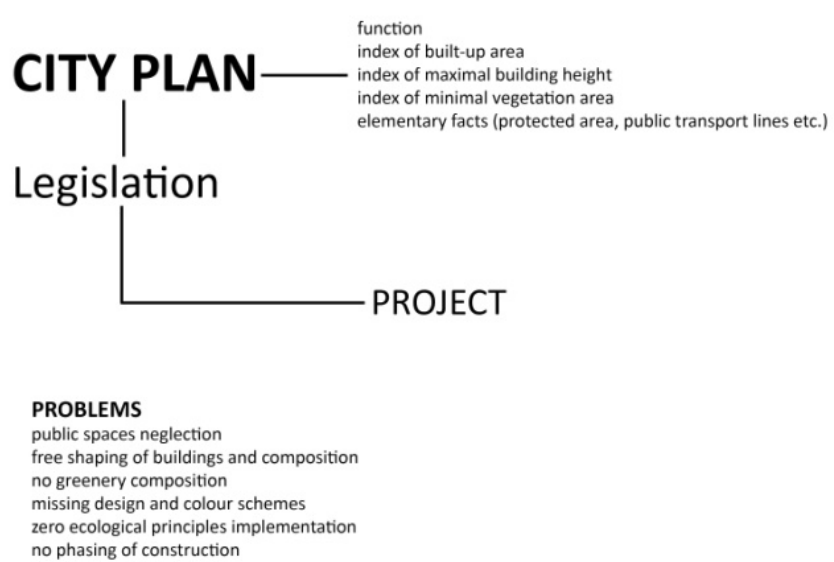

Fig. 5 Simplified scheme of planning process

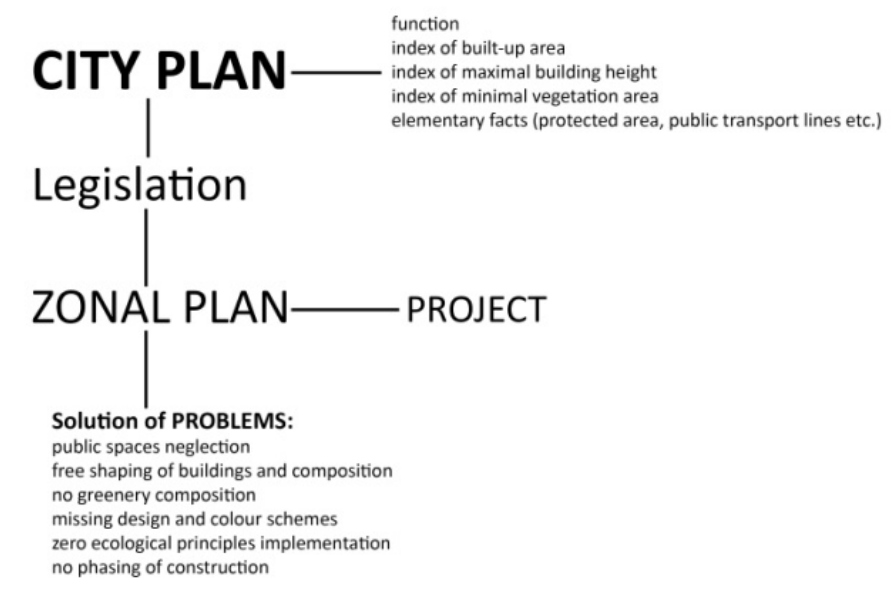

Fig. 6 Simplified scheme of the planning process after implementation of zonal plans

The issuing of zonal plans in Bratislava is supported by the following academics in urban planning: Kováč, Vítková, Moravčíková and Melcerová.

Currently, Bratislava has several zonal plans. However, their solutions focus on some parts of the city only and do not provide an overall coverage of the city's development. The Dúbravka part of the city has no zonal plan. This was one of the criteria for choosing it as an example for the analysis. To design such a plan for one particular city district could lead to the subsequent generalization of principles applicable to other districts in Bratislava. 
The developmental process of zonal plans may not just be a question of funds from the city. It is also a threat in terms of a distortion of the original structure of the system and possible acceptance of changes that may not suit certain parties. It is therefore appropriate to seek conclusive solutions and factors that not only help to create zonal plans but also help to create the basis for their subsequent application.

It would also emphasise the contradiction in the city's master plan, which is now somewhere between the levels of the city and zonal plans. Following the development of zonal plans, the city should not stipulate some parts over others, but rather indicate the basic concept of the hierarchy of the city with a more holistic and less detailed approach. Thereby, a balanced concept between the zonal and city plan can be created. The zonal plans would not exist as an ancillary basis for the concept of the current city plan but lead to a city level redesign of the master plan.

\section{References}

Andrášiová, K., Dulla, M., Haberlandová, K., Moravčíková, H., Pastoreková, L., Szalay, P. (2015) Plánované neplánované mesto: moderné urbanistické koncepcie v tradičnej mestskej štruktúre (preklad). (Planning the Unplanned City: Modern Urban Conceptions in a Traditional Urban Structure.) $A \& U .49(3-4)$, pp. 216-239. (in Slovakian)

Barton, H., Grant, M., Guise, R. (2010) Shaping Neighbourhoods, for Local Health and Global Sustainability. $2^{\text {nd }}$ edition, Routledge, Abingdon

Dulla, M., Moravčíková, H. (2002) Architektúra Slovenska v 20. storočí. (Slovak Architecture in 20th Centrury.) Slovart, Bratislava. (in Slovakian)

Foltyn, L. (1993) Slovenská architektúra a česká avantgarda 1917-1939. (Slovak Architecture and Czech Anvat-garde 1917-1939.) Vzd.Spolku architektov, Bratislava. (in Slovakian)

Görner, K. (2015) Intenzifikácia sídlisk - cesta k ich udržatel'nosti? (Intensification of Settlements, the Way to Their Sustainability?) ALFA. 20(2), pp. 8695. (in Slovakian)
Hnilička, P. (2012) Sídelní kaše. (Urban Sprawl.) Host, Brno. (in Slovakian) Horváth, V. (1990) Bratislavský topografický lexikon (Topographic Lexicon of Bratislava), Tatran, Bratislava. (in Slovakian)

Hruška, E. (1961) Vývoj stavby miest. (Development of Cities.) Vydavatel'stvo Slovenskej Akadémie vied v Bratislave, Bratislava. (in Slovakian)

Jankovich, I. (1988) Uživatel'ský a stavebný experiment v architektúre povojnovej bytovej výstavby. (Building Experiment in Architecture in Postwar residential development.) Projekt. 30(9), p.2. (in Slovakian)

Kusý, M. (1955) Architektúra na Slovensku 1848-1918. (Architecture in Slovakia 1848 -1918.), Bratislava, Bradlo. (in Slovakian)

Kusý, M. (1971) Architektúra na Slovensku 1918 - 1945. (Architecture in Slovakia 1918-1945.), Bratislava, PALLAS vydavatel'stvo SFVU. (in Slovakian)

Kusý, M. (1975) Architektúra na Slovensku 1945 - 1975. (Architecture in Slovakia 1945-1975.), Bratislava. (in Slovakian)

Melcerová, O. (2013) Potenciály polyfunkčného rozvoja sídlisk ilustrované na priklade sídlisk Dúbravka a Prosek. (Potentials of polyfunctional development of mass housing areas illustrated on examples of Dúbravka and Prosek.) ALFA. 18(4), pp. 42-53. (in Slovakian)

Moravčíková, H., Topolčanská M., Szalay, P., Dulla, M., Ščepánová, S., Toscherová, S., Haberlandová, K. (2011) Bratislava Atlas sídlisk. (Bratislava: Atlas of Mass Housing.) SLOVART, Bratislava. (in Slovakian)

Ritchie, A., Thomas, R. (2009) Sustainable Urban Design, an Environmental Approach. Taylor \& Francis, Abingdon

Smit, J., Nasr, J. (1992) Urban agriculture for sustainable cities: Using wastes and idle land and water bodies as resources. Environment and Urbanization. 4(2), pp. 141-152. DOI: 10.1177/095624789200400214

Šášky, L. (1992) Bratislava mesto na Dunaji. (Bratislava city on Danube.) Smena, Bratislava. (in Slovakian)

Štefancová, L., Görner, K. (2015) Intensification of the Main Development Axis of Housing Estates: A Way Towards their Urban Character? In: SGEM 2015. 15th International Multidisciplinary Scientific Geo Conferences SGEM 2015. Nano, Bio and Green - Technologies for a SustainableFuture : conferenceproceedings. Volume II : Green buildings technologies \& materials. Green design \& sustainable architecture, Albena, Bulgaria, June 18-24, 2015. pp. 463-470. DOI: 10.5593/SGEM2015/B62/S27.060 